\title{
Evaluando experiencias gamificadas en docentes y estudiantes de educación física
}

\section{Assessing Gamified Experiences in Physical Education Teachers and Students}

María Elena Parra-González. Universidad de Granada. elenaparra@ugr.es

Adrián Segura-Robles. Universidad de Granada. adrianseg@ugr.es

Elba Rosa Gómez-Barajas. Universidad de Guadalajara, México. elbagomez@valle.udg.mx

\section{RESUMEN.}

Una de las metodologías con mayor auge educativo hoy en día es la gamificación. Esta metodología implica el uso de la mecánica del juego en el aula. El juego se trata como un elemento motivador en el aula, se considera activa porque el alumno debe estar activo en el proceso de aprendizaje y alienta a los estudiantes a ser activos en su proceso de aprendizaje, haciendo que el proceso de enseñanza-aprendizaje sea motivador y efectivo. Se utiliza la escala GAMEX (Gameful Experience in Gamification) para medir la experiencia gamificada. Se analizó la experiencia de 255 estudiantes y profesores en total. Entre los principales resultados obtenidos, destacamos como conclusiones que la gamificación facilita el desarrollo del pensamiento creativo, una reducción del afecto negativo y una mejora en la colaboración. El efecto de este tipo de experiencias es similar tanto en estudiantes como en maestros.

\section{PALABRAS CLAVE.}

Aprendizaje activo, pensamiento creativo, educación, juegos educativos, motivación.

\section{ABSTRACT.}

One of the currently booming methodologies is gamification. Gamification in education involves the use of game mechanics in classroom. The game is treated as a motivating element in the classroom, while this methodology is considered active because the student must be active in the learning process. This methodology is considered active because it encourages students to be active in their learning process, making the teaching-learning process motivating and effective. To develop the research GAMEX scale (Gameful Experience in Gamification) is used to measures the gamified experience, this research analysed the gamification experience of 255 students and teachers in Andalusia in the area of Physical Education, a subject in which game-based learning is a widely used methodology. Among the main results obtained, we highlight as conclusions that gamification facilitates the development of creative thinking, a reduction in negative affect, 
and an improvement in collaboration. The effect of these types of experiences are similar in both students and teachers.

\section{KEY WORDS.}

Active learning, creative thinking, education, educational games, motivation.

\section{Introduction.}

In recent years, gamification has been posited as a solution for involving students and teachers within a much more motivating and effective educational process. It also shows profound changes within the processes of teaching and learning, which seek the introduction of active methodologies within the educational process itself, both for teachers and students. Literature on gamification is increasing and spreading rapidly in many directions. Gamification is still fully in research infancy and is developing rapidly, but what is really known about the phenomenon comes from fragmented pieces of knowledge and a variety of perspectives that attempt to converge on a unified theory (Koivisto \& Hamari, 2019) that really shows the virtues of it. That is, we do not find any unifying theory that is applicable to different fields of knowledge.

Gamified experiences tend to follow the classic patterns of games, such as having fluency and providing the feeling of dominance and increased motivation, especially intrinsic motivation (Ryan, Rigby \& Przybylski, 2006). Gamification has been the centre of great debate as a means to motivate behavioural and psychological results (Hamari, 2013). For Deterding, Dixon, Khaled and Nacke (2011), gamification consists of the integration of game design principles in non-playful contexts. In addition, the main objective in the design and strategies used promotes learning and improves problem-solving (Kapp, 2012).

It is clear that the use of gamified experiences in a classroom increases the motivation of both students and teachers (Erenli, 2013; Lee and Hammer, 2011), thus favouring their learning. However, gamification is not exclusive to the educational sphere; it has been exploited in other areas, such as marketing (Yang, Asaad, \& Dwivedi, 2017).

Although this type of design tends to lead to positive results (Hamari, Koivisto \& Sarsa, 2014), there are other findings that do not show this clearly (de-Marcos, Domínguez, Saenz-deNavarrete, and Pagés, 2014) or even show a negative influence of gamification (Hanus \& Fox, 2015). However, we must remember that the majority of failed gamified experiences are due to a bad original design of the experience (Burke, 2014).

By using elements of game design in its foundation, the intention is to increase the intrinsic motivation of people who are immersed in this type of experience (Shneiderman, 2004). However, to carry them out, it is necessary to plan the tasks and activities that will be developed with the utmost care and consistency. (Von Ahn and Dabbish, 2008).

The benefits of this type of innovative methodology in the educational field have been studied in depth (Piñeiro-Otero and Costa-Sánchez, 2015). Pérez-López and Rivera (2017) emphasized that, for the correct implementation of this type of methodology in a classroom, three main elements must be taken into account: the creation of a good environment in the classroom, the implementation of a methodology that is focused on experience and play, and, finally, the use of shared assessments.

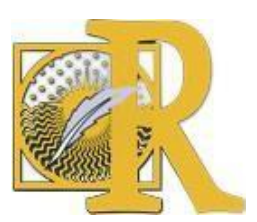


We need to be able to "convince" both students and teachers to be involved in these teaching and learning processes. Gamification is the ideal methodology for this type of challenge (Kapp, 2012; Zichermann and Cunningham, 2011).

Most research on gamification is quite current due, in large part, to the methodological novelty it entails. Some researchers, such as Quintero, Jiménez, and Area (2018), have shown that motivation and cooperative work improve with the use of this type of experience and that the involvement and awareness of students regarding their teaching process improves.

We must be clear that gamification of an experience has nothing to do with game-based learning (GBL). GBL consists of using games in class to learn didactic content, that is, transferring or converting classic games for the classroom to provide students with didactic content. Although the difference is usually not very clear, what indeed is well-defined is the objective of the teachers: to increase students' motivation and excite students (Ayén, 2017). Formal gamification research progresses at a slow pace in terms of improved techniques and design of experiences. In practice, many experiences of this type are carried out, although they are limited to a set of classic elements, such as points, badges, or leaderboards. Researchers, meanwhile, analyse or theorize about these types of experiences without analysing the real effects of these experiences on the participants. Thus, it can be said that research and educational practice are moving away from each other (Rapp, Hopfgartner, Hamari, Linehan \& Cena, 2018).

For all of this, it seems necessary to study which aspects or factors are influenced by using this type of experience, especially in physical education, where the basis of game-based learning is a deeply rooted methodology.

\section{Methods.}

A self-administered online survey was conducted and sent to 500 students and professors belonging to different schools in Andalusia. This questionnaire, the objective of which is to measure which factors influence the development of a gamified experience, should only be completed by respondents who have been immersed, such as teachers during their training or later or as students in some gamified experience.

The GAMEX (Gameful Experience in Gamification) scale, composed of 27 items divided into 6 factors, developed, and validated in English by Eppmann, Bekk \& Klein (2018) was used.

- Enjoyment: Refers to the participant's degree of enjoyment or fun during the experience, capturing whether he/she liked to play the game or enjoyed doing it.

- Absorption: Related to the power of abstraction from reality that the experience produces in participants as well as time-awareness or lack thereof during the experience.

- Creative thinking: Measures the development of creative thinking or creativity fostered by the experience.

- Activation: Factor that measures the ability to activate participants during the experience.

- Absence of negative affect: Captures the development of some negative affect produced in participants during their participation.

- Domain: Assesses the personal sense of control participants have during the experience, if they feel themselves to be participants or leaders during the experience. 
Ultimately, 300 responses were received. All those respondents who indicated that they had not been immersed in a gamified experience in recent months were omitted, leaving a database composed of 255 students and professors whose studies or profession were related directly with physical activity.

The sample consisted of $72.5 \%$ men $(n=185)$ and $27.5 \%$ women $(n=70)$, with $86.3 \%$ of participants under 30 years $(n=220)$ and $13.8 \%$ with an age greater than $30(n=35)$.

All of the questionnaires were administered in a virtual format using the Google Forms platform, which is an efficient tool for data collection through Internet (Mansor, 2012). Participants accessed the platform using the link provided. The tool was configured to preserve the anonymity of participants and prevent them from responding more than once to the same questionnaire.

Regarding data processing, both processing and analysis were performed with SPSS software version 24 . This software allowed us to carry out all of the necessary tests, including both the descriptive tests and the analysis of independent samplesused.

\section{Results.}

First, different internal validation tests of the questionnaire were carried out. Among the tests performed, Cronbach's alpha was calculated, for which values above .90 can be considered acceptable (Zumbo, Gadermann \& Zeisser, 2007). Although this statistic has been widely used in social research, we complemented it with other analyses to avoid biases inherent to the test (Dunn, Baguley \& Brunsden, 2013; Sijtsma, 2008), these being composite reliability (CR) and average variance extracted (AVE) indices. For CR and AVE, values that exceed .7 and .50, respectively, are considered acceptable (Hair \& Gómez Suárez, 2010). In addition, the number of items for each scale is shown (Table 1).

Table 1. Reliability analysis of the scale and factors used.

\begin{tabular}{lcccc} 
& Alpha (a) & CR & AVE & items \\
\hline Enjoyment & .90 & .817 & .642 & 6 \\
Absorption & .89 & .951 & .680 & 6 \\
Creative thinking & .91 & .912 & .720 & 4 \\
Activation & .87 & .854 & .645 & 4 \\
Absence of & .90 & .990 & .750 & 3 \\
negative affect & .93 & .785 & .692 & 4 \\
Domain & .91 & .901 & .633 & 27 \\
Total & & & & \\
\hline
\end{tabular}

For the enjoyment/fun factor, the scores show values close to the maximum value of 5 (Table 2). The scores show high levels in terms of the fun they experienced with this type of activity, with the majority higher than 3.95 and a general average for the factor of $4.14(\mathrm{SD}=.78)$. The Enj6 item stands out ( $\mathrm{M}=4.33$; $\mathrm{SD}=.79)$ and can be considered a good indication of this type of experience's influence on participants. 
Table2. Descriptive and Mean values for the enjoyment/fun factor.

\begin{tabular}{lcc}
\hline \multicolumn{1}{c}{ Enjoyment } & Mean & SD \\
\hline Enj1- Playing was fun & 4.24 & .96 \\
Enj2- I liked playing & 4.01 & .85 \\
Enj3- I enjoyed playing & 3.95 & .86 \\
Enj4- My experience with the game was & 4.19 & .76 \\
pleasant & 4.25 & .90 \\
Enj5- I think playing is very entertaining & 4.33 & .79 \\
Enj6- I would play this game for myself, not & 4.14 & .78 \\
only when asked to do so. & 48 \\
Total
\end{tabular}

For the second factor, called absorption, the values were low compared to those of the previous factor. Its mean was $2.66(\mathrm{SD}=.85)$. The values obtained in $\mathrm{Ab} 1(\mathrm{M}=2.25 ; \mathrm{SD}=.91)$ and Ab6 ( $M=2.30 ; D T=.90)$ stand out because they are especially low (Table 3).

Table 3. Descriptive and Mean values for the absorption factor.

\begin{tabular}{lcc}
\hline \multicolumn{1}{c}{ Absorption } & Mean & SD \\
\hline Ab1- Playing made me forget where I was & 2.25 & .91 \\
Ab2- I forgot my immediate surroundings while I & 3.30 & .93 \\
was playing & & \\
Ab3- After playing, I felt like I returned to the "real & 2.41 & .80 \\
world" after a trip & 3.21 & .82 \\
Ab4- Playing "got me away from everything" & & \\
Ab5- While I was playing, I was completely & 2.50 & .81 \\
oblivious to everything that surrounded me & 2.30 & .90 \\
Ab6- While I was playing, I lost track of time & 2.66 & .85 \\
\hline Total & & \\
\hline
\end{tabular}

For the next analysed factor, creative thinking, and the results show high values (above 4) for the sample (Table 4). The value of Ct2 $(\mathrm{M}=4.40, \mathrm{SD}=.85)$ stands out as the highest value and where the importance of creativity in this type of activity is observed the most. 
Table 4. Descriptives and Mean values for the creative thinking factor.

\begin{tabular}{lcc}
\multicolumn{1}{c}{ Creative thinking } & Mean & SD \\
\hline Ct1- Playing awoke my imagination. & 4.25 & .75 \\
Ct2- While I was playing, I felt creative. & 4.40 & .85 \\
Ct3- While I was playing, I felt I could explore & 4.31 & .79 \\
things. & 4.22 & .90 \\
Ct4- While playing, I felt adventurous. & 4.29 & .93 \\
Total & & \\
\hline
\end{tabular}

Regarding activation, the results for all of the items were above the cut-off score (2.5 out of 5). For this factor, the item Act1 had an average value of $4.75(\mathrm{SD}=.95)$, which was the highest score for the factor (Table 5).

Table 5. Descriptive and Mean values for the activation factor.

\begin{tabular}{lcc}
\hline \multicolumn{1}{c}{ Activation } & Mean & SD \\
\hline Act1- While I was playing, I felt active. & 4.75 & .95 \\
Act2- While I was playing, I felt & 3.10 & .86 \\
nervous. & 3.50 & .85 \\
Act3- While I was playing, I felt frantic. & 3.78 & .98 \\
Total & \\
\hline
\end{tabular}

For the absence of the negative affect, the results were also low. In this case, all were equal or higher than 3.50 (Table 6). The value for item Ane3 stands out ( $M=4.20 ; D T=.82)$. These items must be inverted before being interpreted.

Table 6. Descriptive and Mean values for the absence of negative affect factor.

\begin{tabular}{lcc}
\hline \multicolumn{1}{c}{ Absence of negative affect } & Mean & SD \\
\hline Ane1- While I was playing, I felt annoyed. & 4.15 & .82 \\
Ane2- While I was playing, I felt hostile. & 3.50 & .65 \\
Ane3- While I was playing, I felt frustrated. & 4.20 & .82 \\
Total & 3.95 & .73 \\
\hline
\end{tabular}

For the next factor, domain, the results are varied (Table 7). The lowest value obtained was for item Dom1 ( $M=2.51, D T=.31)$, and the highest average value was for Dom3 ( $M=4.21$; $\mathrm{DT}=.69)$. This difference may be due to the interpretation of the items by the participants. 
Table 7. Descriptives and Mean values for the domain factor.

\begin{tabular}{lcc}
\hline \multicolumn{1}{c}{ Domain } & Mean & SD \\
\hline Dom1- While I was playing, I felt dominant/I had & 2.51 & .31 \\
the feeling of being in charge. & 3.50 & .55 \\
Dom2- While I was playing, I felt influential. & 4.21 & .69 \\
Dom3- While I was playing, I felt autonomous. & 4.01 & .16 \\
Dom4- While playing the game, I felt confident . & 3.55 & .56 \\
Total
\end{tabular}

Subsequently, different mean comparisons were performed using Student's t-tests according to the age of the participants. The results presented in Table 8 show that there were no significant differences ( $p>.05$ ) in any of the factors studied for any of the age groups studied.

Table 8. Student's $t$-tests for groups according to age.

\begin{tabular}{|c|c|c|c|c|}
\hline Factor & Age & Mean & $t$ & p Value \\
\hline Enjoyment & $\begin{array}{l}>30 \\
<30\end{array}$ & $\begin{array}{l}25.23 \\
24.05\end{array}$ & -3.313 & .05 \\
\hline Absorption & $\begin{array}{l}>30 \\
<30\end{array}$ & $\begin{array}{l}26.02 \\
24.15\end{array}$ & -4.221 & .08 \\
\hline Creative thinking & $\begin{array}{l}>30 \\
<30\end{array}$ & $\begin{array}{l}19.02 \\
17.05\end{array}$ & -3.547 & .06 \\
\hline Activation & $\begin{array}{l}>30 \\
<30\end{array}$ & $\begin{array}{l}20.20 \\
20.35\end{array}$ & 4.259 & .06 \\
\hline $\begin{array}{l}\text { Absence of } \\
\text { negative affect }\end{array}$ & $\begin{array}{l}>30 \\
<30\end{array}$ & $\begin{array}{l}15.52 \\
12.2\end{array}$ & 4.331 & .08 \\
\hline Domain & $\begin{array}{l}>30 \\
<30\end{array}$ & $\begin{array}{l}\overline{11.42} \\
13.53\end{array}$ & 2.220 & .08 \\
\hline
\end{tabular}

For gender, the results show (Table 9), as with the age groups analysed above, no differences for any of the factors analysed. The type of participant was not a differentiating variable for this type of experience. 
Table 9. Student's t tests for groups according to participant type.

\begin{tabular}{llllc}
\hline \multicolumn{1}{c}{ Factor } & $\begin{array}{c}\text { Participant } \\
\text { type }\end{array}$ & Mean & t & p Value \\
\hline \multirow{2}{*}{ Enjoyment } & $\begin{array}{l}\text { Professor } \\
\text { Student }\end{array}$ & $\begin{array}{r}25.02 \\
26.05\end{array}$ & 6.413 & .06 \\
\cline { 2 - 5 } Absorption & $\begin{array}{l}\text { Professor } \\
\text { Student }\end{array}$ & $\begin{array}{r}23.02 \\
24.15\end{array}$ & -1.241 & .08 \\
\cline { 2 - 5 } Creative thinking & $\begin{array}{l}\text { Professor } \\
\text { Student }\end{array}$ & $\begin{array}{l}21.22 \\
11.65\end{array}$ & -2.607 & \multirow{2}{*}{.07} \\
\cline { 2 - 5 } Activation & $\begin{array}{l}\text { Professor } \\
\text { Student }\end{array}$ & $\begin{array}{l}22.30 \\
18.45\end{array}$ & \multirow{2}{*}{3.209} & \multirow{2}{*}{.26} \\
\cline { 2 - 5 } Absence of negative affect & $\begin{array}{l}\text { Professor } \\
\text { Student }\end{array}$ & $\begin{array}{l}13.65 \\
10.25\end{array}$ & -3.341 & \multirow{2}{*}{.71} \\
\cline { 2 - 5 } Domain & $\begin{array}{l}\text { Professor } \\
\text { Student }\end{array}$ & $\begin{array}{l}11.42 \\
18.23\end{array}$ & 1.230 & \multirow{2}{*}{35} \\
\hline
\end{tabular}

\section{Discussion.}

The results obtained are different and deserve to be analysed. To facilitate their discussion, the same structure is followed as in the presentation of the results.

With regard to fun/enjoyment, the results show very high values. This type of result is not uncommon, as this type of experience has always been highlighted in the literature as one of the most valued aspects (Fang \& Zhao, 2010, Rodrigues, Oliveira \& Costa, 2016).

As for the absorption factor, results did not reveal particularly low or high values. These results are in contrast with other studies that have shown a real ability to remove participants from the immediate environment or place where the experience was developed (Kalinauskas, 2014, Robson, Plangger, Kietzmann, McCarthy \& Pitt, 2015). In view of these results, it is recommended that the wording of the items be reviewed because the wording may be the cause of these results.

Regarding the factor "creative thinking", which allows students to produce something new or original or find solutions that are not evident (Kingsley \& Grabner-Hagen, 2015), the results were quite high, ranking as one of the factors that participants valued the most (Prince, 2013). As for activation, the results are consistent with other studies (Roth, Schneckenberg \& Tsai, 2015). Activation is not a new phenomenon, as it has usually been related to intrinsic motivation (Csikszentmihalyi, 2002; Hanus \& Fox, 2015; MacKinnon et al., 2015; Perryer, Celestine, Scott-Ladd \& Leighton, 2016). Thus, if motivation is a fundamental value of this type of experience, activation must also be one.

Another important aspect is the absence of negative affect during the gamified experiences. Values obtained show that this type of experience does not create any type of conflict between participants, nor do they feel any type of discomfort during the development of the game. This factor is an essential indicator when evaluating this type of experience (Hall, Glanz, Caton, \& Weinhardt, 2013). 
Regarding domain, results did not show a clear preference on behalf of participants, with both high and low scores. Although this factor has been studied in other publications (Brady, Devitt, Lamest \& Pearson, 2015), the reality is that it is almost always done from a game-based learning perspective. However, it is still a key factor from a more psychological perspective (Bakker, Van der Voordt, Vink \& de Boon, 2014). In view of this, it is recommended that this factor be considered with caution in possible future investigations, and this factor may need to be rethought.

The different mean contrasts that were tested did not reveal significant differences, showing that the effects of this type of activity are not influenced by other variables, such as age (Koivisto \& Hamari, 2014). There are also no differences around the type of participant. These results coincide with similar studies in which the majority of sociodemographic variables do not show a direct influence on the scores obtained (Hursen \& Bas, 2019).

\section{Conclusions.}

The results obtained during this study show the importance and influence of this type of experience for participants. In addition, the positive effects that they can have on learning are highlighted, such as development of creative thinking, reduction of negative affect and improvement in collaboration.

Therefore, as in other related studies, the importance of gamification for teaching and learning processes is demonstrated once again as well as how it is a positive influence. Moreover, no negative effects were observed that would support excluding from in other educational environments.

Although we might think that in physical education learning is already implicitly based on games, emotions, and fun, we should consider going further and applying structures specific to gamification to the experiences that we develop.

\section{References.}

- Ayén, F. (2017). ¿Qué es la gamificación y el ABJ? [What is gamification and GBA?] Iber: Didáctica de las ciencias sociales, geografía e historia, 86, 7-15.

- Burke, B. (2014). Gamify. Brookline, MA: Bibliomotion, Incorporated.

- Csikszentmihalyi, M. (2002). Flow: The Psychology of Happiness. London: Ebury Publishing.

- De-Marcos, L., Domínguez, A., Saenz-de-Navarrete, J., \& Pagés, C. (2014). An empirical study comparing gamification and social networking on e-learning. Computers \& Education, 75, 82-91. doi: 10.1016/j.compedu.2014.01.012

- Deterding, S., Dixon, D., Khaled, R., \& Nacke, L. (2011). From game design elements to gamefulness. Proceedings of the 15Th International Academic Mindtrek Conference on Envisioning Future Media Environments - Mindtrek '11. doi: 10.1145/2181037.2181040

- Dunn, T., Baguley, T., \& Brunsden, V. (2013). From alpha to omega: A practical solution to the pervasive problem of internal consistency estimation. British Journal of Psychology, 105(3), 399-412. doi: 10.1111/bjop.12046 
- Eppmann, R., Bekk, M., \& Klein, K. (2018). Gameful Experience in Gamification: Construction and Validation of a Gameful Experience Scale [GAMEX]. Journal of Interactive Marketing, 43, 98-115. doi: 10.1016/j.intmar.2018.03.002

- Erenli, K. (2013). The impact of gamification: Recommending education scenarios. International Journal of Emerging Technologies in Learning, 8(SPL.ISSUE), 15-21.

- Fang, X., \& Zhao, F. (2010). Personality and enjoyment of computer game play. Computers in Industry, 61(4), 342-349. doi: 10.1016/j.compind.2009.12.005

- Hair, J., \& Gó mez Suá rez, M. (2010). Análisis multivariante [Multivariate analysis]. Madrid: Prentice-Hall.

- Hamari, J. (2013). Transforming homo economicus into homo ludens: A field experiment on gamification in a utilitarian peer-to-peer trading service. Electronic Commerce Research and Applications, 12(4), 236-245. doi: 10.1016/j.elerap.2013.01.004

- Hamari, J., Koivisto, J., \& Sarsa, H. (2014). Does Gamification Work? -- A Literature Review of Empirical Studies on Gamification. 2014 47Th Hawaii International Conference on System Sciences. doi: 10.1109/hicss.2014.377

- Hanus, M., \& Fox, J. (2015). Assessing the effects of gamification in the classroom: A longitudinal study on intrinsic motivation, social comparison, satisfaction, effort, and academic performance. Computers \& Education, 80, 152-161. doi: 10.1016/j.compedu.2014.08.019

- Hursen, C., \& Bas, C. (2019). Use of Gamification Applications in Science Education. International Journal Of Emerging Technologies In Learning (ljet), 14(01), 4. doi: 10.3991/ijet.v14i01.8894

- Kalinauskas, M. (2014). Gamification in Fostering Creativity. Social Technologies, 4(1), 62-75. doi: 10.13165/st-14-4-1-05

- Kapp, K.M. (2012). The Gamification of learning and Instruction. San Francisco: John Wiley.

- Koivisto, J., \& Hamari, J. (2014). Demographic differences in perceived benefits from gamification. Computers in Human Behavior, 35, 179-188. doi: 10.1016/j.chb.2014.03.007

- Lee, J. J. y Hammer, J. (2011). Gamification in Education: What, How, Why Bother. Academic Exchange Quaterly, 15(2).

- Mansor, A. (2012). Managing Student's Grades and Attendance Records using Google Forms and Google Spreadsheets. Procedia - Social And Behavioral Sciences, 59, 420428. doi: 10.1016/j.sbspro.2012.09.296

- MacKinnon, R., Stoeter, R., Doherty, C., Fullwood, C., Cheng, A., \& Nadkarni, V. et al. (2015). Self-motivated learning with gamification improves infant CPR performance, a randomised controlled trial. BMJ Simulation And Technology Enhanced Learning, 1(3), 71-76. doi: 10.1136/bmjstel-2015-000061

- Pérez-López, I. y Rivera García, E. (2017). Formar docentes, formar personas: análisis de los aprendizajes logrados por estudiantes universitarios desde una experiencia de gamificación [Train teachers, train people: analysis of the learning achieved by university students from a gamification experience]. Signo y Pensamiento, 36(70), 112-129. doi: 10.11144/Javeriana.syp36-70.fdfp 
- Perryer, C., Celestine, N., Scott-Ladd, B., \& Leighton, C. (2016). Enhancing workplace motivation through gamification: Transferrable lessons from pedagogy. The International Journal Of Management Education, 14(3), 327-335. doi: 10.1016/j.jjme.2016.07.001

- Piñeiro-Otero, T. y Costa-Sánchez, C. (2015). ARG (juegos de realidad alternativa). Contribuciones, limitaciones y potencialidades para la docencia universitaria [ARG (alternative reality games). Contributions, limitations and potential for university teaching]. Comunicar, 44(22), 141-148.

- Rapp, A., Hopfgartner, F., Hamari, J., Linehan, C., \& Cena, F. (2018). Strengthening gamification studies: Current trends and future opportunities of gamification research. International Journal Of Human-Computer Studies. doi: 10.1016/j.ijhcs.2018.11.007

- Robson, K., Plangger, K., Kietzmann, J., McCarthy, I., \& Pitt, L. (2015). Is it all a game? Understanding the principles of gamification. Business Horizons, 58(4), 411-420. doi: 10.1016/j.bushor.2015.03.006

- Rodrigues, L., Oliveira, A., \& Costa, C. (2016). Does ease-of-use contributes to the perception of enjoyment? A case of gamification in e-banking. Computers In Human Behavior, 61, 114-126. doi: 10.1016/j.chb.2016.03.015

- Roth, S., Schneckenberg, D., \& Tsai, C. (2015). The Ludic Drive as Innovation Driver: Introduction to the Gamification of Innovation. Creativity and Innovation Management, 24(2), 300-306. doi: 10.1111/caim.12124

- Ryan, R., Rigby, C., \& Przybylski, A. (2006). The Motivational Pull of Video Games: A Self-Determination Theory Approach. Motivation And Emotion, 30(4), 344-360. doi: 10.1007/s11031-006-9051-8

- Shneiderman, B. (2004) Designing for Fun: How Can We Design User Interfaces to Be More Fun? Interactions, 11 (5), 48-50

- Sijtsma, K. (2008). On the Use, the Misuse, and the Very Limited Usefulness of Cronbach's Alpha. Psychometrika, 74(1), 107-120. doi: 10.1007/s11336-008-9101-0

- Quintero, L., Jiménez, F. y Area, M. (2018). Más allá del libro de texto. La gamificación mediada con TIC como alternativa de innovación en Educación Física [Beyond the textbook. ICT-mediated gamification as an innovation alternative in Physical Education]. Retos: nuevas tendencias en educación física, deporte y recreación, 34, 343-348.

- Zichermann, G. y Cunningham, C. (2011). Gamification by Design: Implementing Game Mechanics in Web and Mobile Apps. Cam bridge: O'Reilly Media.

- Von Ahn, L., y Dabbish, L. (2008). Designing games with a purpose. Communications Of The ACM, 51(8), 57. doi: 10.1145/1378704.1378719

- Yang, Y., Asaad, Y., \& Dwivedi, Y. (2017). Examining the impact of gamification on intention of engagement and brand attitude in the marketing context. Computers in Human Behavior, 73, 459-469. doi:10.1016/j.chb.2017.03.066

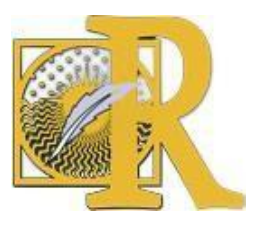

